\title{
Creation of reference DNA barcode library and authentication of medicinal plant raw drugs used in Ayurvedic medicine
}

\author{
Sophie Lorraine Vassou, Stalin Nithaniyal, Balaji Raju and Madasamy Parani*
}

\begin{abstract}
Background: Ayurveda is a system of traditional medicine that originated in ancient India, and it is still in practice. Medicinal plants are the backbone of Ayurveda, which heavily relies on the plant-derived therapeutics. While Ayurveda is becoming more popular in several countries throughout the World, lack of authenticated medicinal plant raw drugs is a growing concern. Our aim was to DNA barcode the medicinal plants that are listed in the Ayurvedic Pharmacopoeia of India (API) to create a reference DNA barcode library, and to use the same to authenticate the raw drugs that are sold in markets.

Methods: We have DNA barcoded 347 medicinal plants using rbcL marker, and curated rbcL DNA barcodes for 27 medicinal plants from public databases. These sequences were used to create Ayurvedic Pharmacopoeia of India Reference DNA Barcode Library (API-RDBL). This library was used to authenticate 100 medicinal plant raw drugs, which were in the form of powders (82) and seeds (18).

Results: Ayurvedic Pharmacopoeia of India - Reference DNA Barcode Library (API-RDBL) was created with high quality and authentic rbcL barcodes for 374 out of the 395 medicinal plants that are included in the API. The rbcL DNA barcode differentiated 319 species (85\%) with the pairwise divergence ranging between 0.2 and $29.9 \%$. PCR amplification and DNA sequencing success rate of $r b c L$ marker was $100 \%$ even for the poorly preserved medicinal plant raw drugs that were collected from local markets. DNA barcoding revealed that only $79 \%$ raw drugs were authentic, and the remaining $21 \%$ samples were adulterated. Further, adulteration was found to be much higher with powders (ca. $25 \%$ ) when compared to seeds (ca. $5 \%$ ).

Conclusions: The present study demonstrated the utility of DNA barcoding in authenticating medicinal plant raw drugs, and found that approximately one fifth of the market samples were adulterated. Powdered raw drugs, which are very difficult to be identified by taxonomists as well as common people, seem to be the easy target for adulteration. Developing a quality control protocol for medicinal plant raw drugs by incorporating DNA barcoding as a component is essential to ensure safety to the consumers.
\end{abstract}

\section{Background}

Ayurveda is one of the most ancient systems of traditional medicine, which originated in India about 5000 years ago [1]. As science of life ('ayur' means 'life' and 'veda' means 'knowledge' in Sanskrit), Ayurveda focuses on the holistic approach towards a healthy life, not merely on curing of diseases. Ayurveda is based on the principle that both the universe and the human body are made up of five elements. A balanced state of these

\footnotetext{
* Correspondence: parani.m@ktr.srmuniv.ac.in

Department of Genetic Engineering, Center for DNA Barcoding, SRM

University, Kattankulathur 603203, India
}

elements in the body gives good health, and an imbalance brings illness or disease [2]. It is a detailed system of traditional medicine with eight distinct branches and 16 specialties including internal medicine, surgery (includes plastic surgery), pediatrics, obstetrics, gynecology, psychiatry, toxicology, and geriatrics [3]. Ayurveda is not a simple herbal medicine; it provides a detailed account of drug preparation using herbs, detoxification and proper administration with the required dosage. It is the oldest medical system to offer patient-centric personalized medicine. Therefore, Ayurveda bears all the qualities of a distinct medical system in its own strength.

(c) 2016 The Author(s). Open Access This article is distributed under the terms of the Creative Commons Attribution 4.0 International License (http://creativecommons.org/licenses/by/4.0/), which permits unrestricted use, distribution, and reproduction in any medium, provided you give appropriate credit to the original author(s) and the source, provide a link to the Creative Commons license, and indicate if changes were made. The Creative Commons Public Domain Dedication waiver (http://creativecommons.org/publicdomain/zero/1.0/) applies to the data made available in this article, unless otherwise stated. 
However, extensive modern experimental research and regulatory system are required to make it a standardized, effective and safe system of medicine.

Owing to the excellent education system that prevailed in the ancient India, the bibliographic account of Ayurveda is well documented. Atharva Veda (1500 to 1000 $\mathrm{BC}$ ) is considered the first written document of Ayurveda containing the description of certain diseases, and methods of curing them [4]. The two other important ancient treatises on Ayurveda are Charaka Samhita (1000 BC), which deals with internal medicine explaining the logic and philosophy of Ayurvedic medicine [5, 6], and Sushruta Samhita (1000 BC), which deals with surgery, and the diseases of special organs such as the eye, ear, throat, nose, head and dentistry $[7,8]$. These treatises were used for the institutionalized teaching of Ayurveda in the Department of Ayurveda, which was established as early as 7th century in the ancient Takshashila University in India (now in Pakistan) [9]. It is around this time, Ashtanga Hridaya was written with the detailed explanation of the principles and practices of Ayurvedic medicine. Subsequently, many texts, compendia, and updates were written to further expand the knowledge. However, the principles and philosophy of Ayurveda remained the same. At present, there are 57 authoritative textbooks for practicing Ayurveda in India and elsewhere [10].

Ayurveda is being continuously practiced in India from ancient times, and at present, it is one of the mainstream official systems of medicine with sufficient infrastructure for healthcare service and education. Education in Ayurvedic medicine is offered at the undergraduate (five and an half year program), postgraduate (MD/MS in more than 20 specialties), and Ph.D. levels in India. A huge network of 429,246 registered practitioners, 2420 Ayurveda hospitals and 15,017 dispensaries offer healthcare to the people [2]. It is also becoming popular in other countries including Latin American countries, Europe and the USA [11]. High cost and increasing awareness about the side effects of allopathy drugs, especially in case of chronic diseases, are the main driving forces that favor the adoption of naturebased Ayurvedic medicine.

Until a century ago, all medicines were non-synthetic, and mostly came from plants. Therefore, it is no surprise that plants are the major source of therapeutic ingredients in Ayurveda also. Atharva Veda (1500-1000 BC) mentions 293 medicinal plants [12]. Charaka Samhita (1000 BC) and Sushruta Samhita (1000 BC) contain the names of 341 and 395 medicinal plants, respectively [13, 14]. Ashtanga Hridaya described the largest number of 902 medicinal plants [15]. The medicinal plants in theses treatises were given simple Sanskrit names much before the modern Linnaean taxonomy with binomial names was proposed in the 18th century. Presently, the Ayurvedic Pharmacopoeia of India (API) is the legal document of standards for the quality of Ayurvedic drugs and substances included therein [16-21]. The six volumes of API list 395 medicinal plants, which can be officially used for the preparation of single drugs (each drug is derived from one plant or plant part). Use of the correct plant species is the basic requirement to get the desired benefits of Ayurveda. Dwindling natural supplies at the time of increasing domestic and global demand for the medicinal plants increases the probability of adulteration, which can greatly affect the efficacy and safety of Ayurvedic medicine. Morphological species identification for monitoring adulteration in plant materials is a great challenge, especially when the plants are purchased as raw drugs (dried or powdered whole plant or plant parts), which often lack the key morphological diagnostic characters that are required for species identification. The present study is the first attempt to DNA barcode the medicinal plants that are listed in API so as to develop a molecular tool to identify them in fresh as well as raw drug form. For this purpose, first we have compiled the list of plants in API with currently accepted scientific names. Then, we have collected fresh plant specimens and DNA barcoded them to generate Ayurvedic Pharmacopoeia of India - Reference DNA Barcode Library (API-RDBL). Subsequently, this library was used for species identification by DNA barcoding of the raw drugs that were collected from markets.

\section{Methods}

\section{Collection of plant samples}

The monographs in the API contain the Sanskrit and botanical names of the plants. Since these monographs were written between the year 1990 and 2008 (Ayurvedic Pharmacopoeia of India Part - I, Volumes I to VI), we have revised the name of the plants by incorporating the currently accepted botanical names as given in Tropicos and The Plants List database. We have prepared the API plant list that contains the Sanskrit names, the botanical names used in the API and the currently accepted botanical names for the 395 plants (see Additional file 1: Table S1). Throughout this study only the currently accepted botanical names as given in API plant list were used. Four medicinal plants in the API plant list are not available in India, and hence imported as raw drugs from other countries. Some medicinal plants in the API plant list were difficult to collect due to their seasonal occurrence or distribution in the high altitude ranges of the Himalayas. Most of the fresh specimens of the medicinal plants were collected from open forests, cultivated fields and botanical gardens of research institutions. Some specimens were derived from the seedlings that were raised from seeds in the greenhouse. 
Altogether, we have collected fresh specimens for 347 medicinal plants in the API plant list. Name of the plant, Sample ID, Field ID, and the place of collection are given in (see Additional file 2: Table S2). Voucher specimens were prepared and identified using local floras, mounted on standard herbarium sheets, and deposited in the SRM University Herbarium. Fresh leaves were used for DNA isolation, and air-dried samples were retained for future reference.

\section{Curated data from public databases}

The GenBank and BOLD databases were searched for the presence of $r b c L$ sequences from the medicinal plants for which we could not collect specimens for DNA isolation. The curated $r b c L$ barcodes from these databases were included in the present study.

\section{Collection of raw drugs}

Samples of the medicinal plant raw drugs in the form of powders and seeds were collected from the herbal markets in Chennai, Tamil Nadu, India.

\section{DNA extraction, PCR amplification and sequencing}

Genomic DNA was extracted from either $100 \mathrm{mg}$ of fresh leaf tissue or $25 \mathrm{mg}$ of raw drugs using the cetyl trimethyl ammonium bromide (CTAB) method [22] as described before [23]. The DNA was checked on $0.8 \%$ Agarose gel and quantified for PCR amplification. Polymerase chain reaction (PCR) was performed using $r b c L a F$ (ATGTCACCACAAACAGAGACTAAAGC), $r b c$ Lajf634R (GAAACGGTCTCTC CAACGCAT) primers [24, 25]. The amplicons were checked on $1 \%$ agarose gel, and purified using EZ-10 Spin Column PCR Purification Kit (Bio Basic Inc. Ontario, Canada). Samples were sequenced using 3130xl Genetic analyzer (Applied Biosystems, CA, USA). The sequences were manually edited using Sequence Scanner Software v1.0 (Applied Biosystems, CA, USA), and full-length sequences were assembled using local alignment algorithm of CodonCode Aligner, version 4.2.4 (CodonCode Corporation, MA, USA).

\section{Sequence analyses}

BLAST search was performed against GenBank (http:// blast.ncbi.nlm.nih.gov/Blast.cgi) and BOLD (http:// www.boldsystems.org/index.php/databases) databases. TaxonDNA v. 1.6.2 (http://taxondna.sf.net/) was used to calculate pairwise divergence [26]. Phylogenetic tree based on Neighbour-Joining (NJ) method was constructed using MEGA version 5.1 [27]. Best match method was used for the authentication of the raw drug market samples [26]. Unmatched samples were analyzed by BLAST search against the NCBI nucleotide database and BOLD database.

\section{Results and discussion}

It is estimated that about 1587 plants are used for the preparation of various kinds of Ayurvedic medicines [28]. Ayurvedic Pharmacopoeia of India (API) officially recommends 395 medicinal plants for the preparation of 519 Ayurvedic single drugs. The present study included 347 of them, which belong to 308 genera, 112 families and 45 orders. DNA isolation, PCR amplification and DNA sequencing of the $r b c L$ marker were successful with all these plants. The same level of success was observed with the raw drugs, which were stored at room temperature without any special care to preserve the DNA. Therefore, $r b c L$ would be a robust marker for creating reference DNA barcode library for the API plants, and authenticating poorly preserved market samples. Size of the $r b c L$ barcodes generated in the present study was 607 bp with the $Q$ value $\geq 40$. Being a highly conserved and maternally inherited chloroplast marker, $r b c L$ query sequence is expected to show the highest identity with the sequence from the same species or closely related species. Therefore, nucleotide BLAST analysis of the $r b c L$ sequences can be used as a quality control measure to flag potential morphological misidentifications or sample mix up. In nucleotide BLAST analysis, the $r b c L$ sequences from all the 347 medicinal plants showed the highest identity with sequences from the same species (148) or congeneric species (145) or species from a closely related genus of the same family (54). These results provided initial DNA based validation for the taxonomic identity of the medicinal plants that were collected for the current study. However, this validation will not be reliable if the taxonomic identity of the sequence in the database was incorrect. This problem can be addressed by constructing phylogenetic tree wherein the wrongly identified samples are highly likely to be placed in unexpected clades. As shown in Fig. 1, the phylogenetic tree showed placing of all the species in appropriate clades as would be expected based on phylogenetic relationships among the flowering plants as per APG III classification. Therefore, taxonomic fidelity of the $r b c L$ sequences that was generated from the current study can be considered as high. These sequences were submitted to the BOLD Systems under the accession numbers [SRM301A to SRM600A and SRM618A to SRM671A].

In addition, we have supplemented our data by adding $r b c L$ sequences for 27 plants, which were curated from GenBank and BOLD databases. All the curated sequence data satisfied the criteria of i) the sequence is associated with publications in refereed journals or unpublished data from scientists with good publication record in taxonomy or DNA barcoding, ii) the sequence shows highest identity with sequences from congeneric species, iii) the sequence is placed in the clade that is appropriate to 


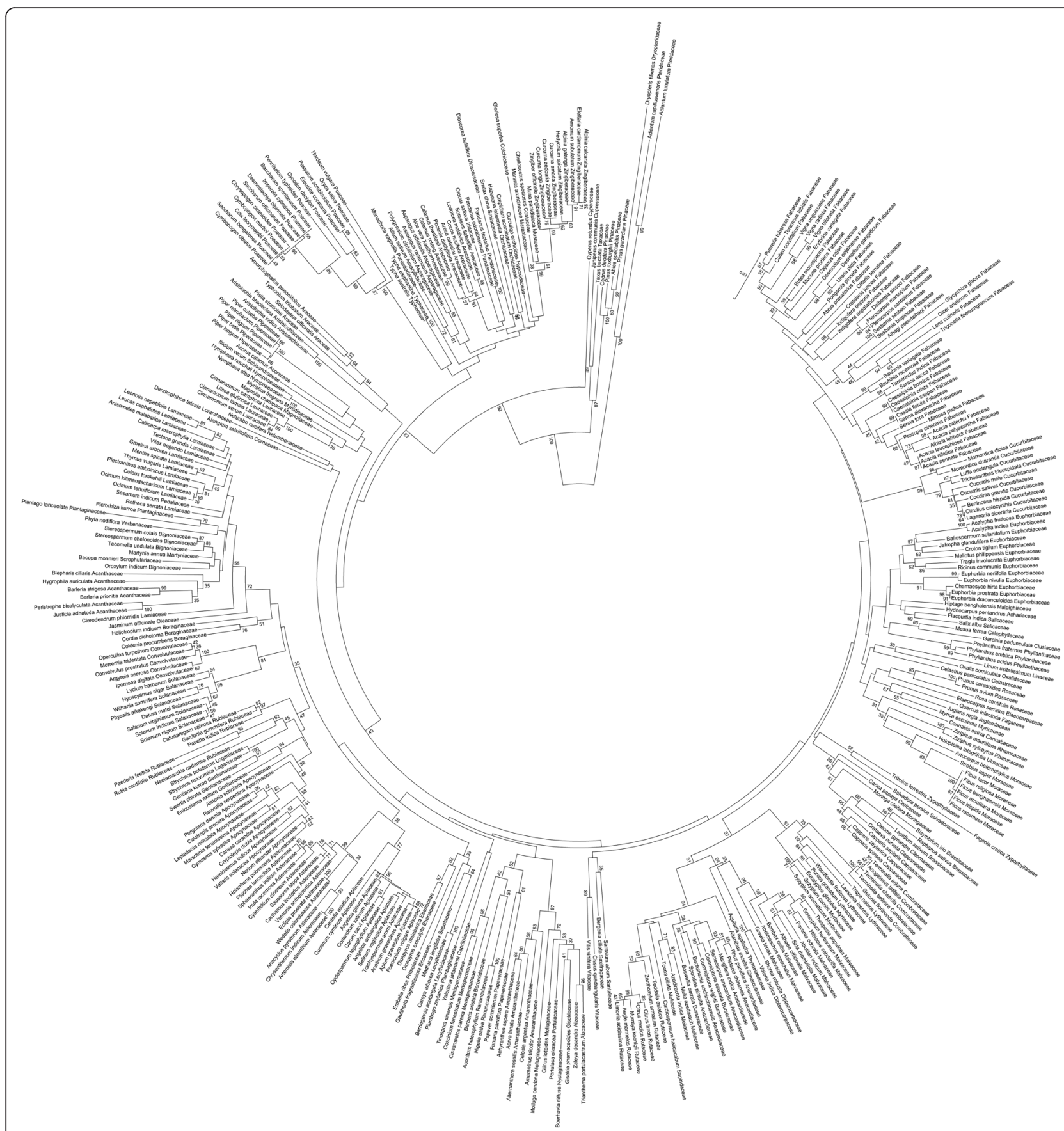

Fig. 1 Phylogenetic tree constructed using Neighbour-Joining (NJ) method for 374 rbcL sequences for the Ayurvedic Pharmacopoeia of India - Reference DNA Barcode Library (API-RDBL)

its taxonomic affiliation (Fig. 1), and iv) at least one sequence of $500 \mathrm{bp}$ length is available. Details of the 27 medicinal plants in the API plant list for which the $r b c L$ sequences were curated from GenBank and BOLD databases are given in Additional file 3: Table S3 [29-43]. Size of the curated $r b c L$ sequences ranged between 502 and $607 \mathrm{bp}$. Since the Consortium for the Barcode of Life (CBOL) recommends $500 \mathrm{bp}$ as acceptable DNA barcode size, all the sequences included in our study are suitable to be used as DNA barcode marker. Together, $r b c L$ sequences from 374 medicinal plants were used to generate Ayurvedic Pharmacopoeia of India - Reference DNA Barcode Library (API-RDBL).

Pairwise divergence was calculated to determine the ability of the $r b c L$ marker to differentiate the 374 species that are currently represented in the API-RDBL. It was 
found that 319 species ( $85 \%$ ) could be successfully differentiated with the pairwise divergence ranging between 0.2 and $29.9 \%$. There were 55 undifferentiated species, which included 38 congeneric species from 17 genera, each with 2 to 6 species. Differentiation of these species would require the use of other coding (matK) or noncoding markers (trn H-psbA, ITS2, and others). Alternatively, a tiered approach of combining one coding marker with another non-coding marker can be more effective as it helps to overcome the problem in alignment that is encountered with the sequences from non-coding markers. In this approach, a structurally conserved marker acts as scaffold (first tier marker) on which the data from a variable noncoding marker is placed [44, 45]. Due to its high universality, and unparalleled PCR amplification and DNA sequencing success rates, $r b c L$ could be considered as an ideal first tier marker. The $r b c L$ marker is particularly useful in DNA barcoding of the medicinal plants used in Ayurveda because the major application for it would be the authentication of raw drugs, which necessitates amplification of the barcode sequences from taxonomically diverse and poorly preserved market samples. Recently, Parvathy et al. (2015) reported that $r b c L$ but not matK could be amplified from the market samples of turmeric powders [46].

Excepting a few practitioners who make their own collections, the plant materials used in Ayurveda are normally procured as raw drugs from the markets. Therefore, these raw drugs must be authentic to derive the expected benefits of the Ayurvedic medicines that are made out of them. However, the raw drugs trade is largely unregulated, and as a result, spurious raw drugs are often found in the markets. Adulterations in the range of 18 to $59 \%$ were reported in the herbal products, commercial medicinal plants, and natural health products [47-49]. DNA barcoding is undoubtedly having a high impact on quality control of herbal products and raw drugs $[49,50]$. Therefore, we have explored the possibility of using the API-RDBL to authenticate the raw drugs of the medicinal plants that are in the API plant list. We have collected 100 raw drugs: 82 in the form of powders and 18 in the form of seeds. Vernacular name of the raw drug (Tamil), name of the corresponding medicinal plant (Sanskrit name as given in the API), and currently accepted botanical name are given in (see Additional file 4: Table S4). The $r b c L$ reference sequences (derived from the corresponding plant specimens) for all these 100 raw drugs were present in the API-RDBL. Extraction of genomic DNA and DNA sequencing of the $r b c L$ marker were successful with all the raw drugs. By comparing these sequences with that in the API-RDBL, only 79 raw drugs were found to be authentic as their $r b c L$ sequences showed $100 \%$ identity with the reference sequence of the expected species. The remaining 21 raw drugs (21\%) were found to be not authentic as their $r b c L$ sequences showed only 85 to $98 \%$ identity with the reference sequence of the expected species. Obviously, these raw drugs must be eliminated from the markets because Ayurvedic medicines that are made out of such spurious raw drugs are not likely to give the desired therapeutic effects. It may also give adverse or toxic effect depending on the nature of the plant materials that are present in the unauthentic raw drugs. Interestingly, unauthentic raw drugs were significantly more frequent in powders than in seeds (ca. $25 \%$ versus ca. $5 \%$ ). The possible reason is that the plant parts after grinding to powders are very difficult for the morphological identification by taxonomists or common people, which makes them vulnerable for adulteration. On the other hand, seeds have the same morphology as plant part and as raw drug, which makes it easier for identification and less vulnerable to adulteration.

It is beyond the scope of this study to establish the species identity of the plant materials that are present in the unauthentic raw drugs. However, BLAST analysis of the $r b c L$ sequences from theses samples against the GenBank and BOLD databases indicated that the raw drug samples named as Abies spectabilis and Glycyrrhiza glabra might have been actually derived from Taxus fuana and Azadirachta indica, respectively. Abies spectabilis is used in Ayurveda for the treatment of asthma, cough, abdominal lump, digestive impairment, pthisis, hiccough, emesis, worm infestation, diseases of the mouth and tastelessness [19], but we did not find any Ayurvedic medicinal use for Taxus fuana. While Glycyrrhiza glabra is used in Ayurveda for the treatment of cough, hoarseness of voice, pthisis, ulcer and gout [16], Azadirachta indica is used for treating emesis, skin diseases, bleeding and urinary disorders, nausea, non-healing ulcer, thirst, fever, burning sensation, cough, asthma, inflammation, worm infestation, tastelessness, liver disease, heart burn, and vomiting [20]. These results clearly show the enormity of the problem that might arise due to the use of unauthentic raw drugs in Ayurveda.

\section{Conclusion}

The present study established for the first time a reference DNA barcode library for the medicinal plants in the API plant list. It clearly showed that unauthentic medicinal plant raw drugs are sold in the herbal markets, and DNA barcoding will be highly useful to identify the same. Other markers are to be explored to identify the species that were not differentiated by the $r b c L$ marker. DNA barcoding of the species that are taxonomically closely related to the authentic species, potential adulterant species, co-occurring species will strengthen this technology further. 


\section{Additional files}

Additional file 1: Table S1. Sanskrit name, botanical name given in the $\mathrm{API}$, and the currently accepted botanical name for the 395 medicinal plants that are listed in API. (XLS 89 kb)

Additional file 2: Table S2. Name of the species, sample ID, field ID and the place of collection of the specimens of the plants that are listed in the API. (XLS $84 \mathrm{~kb}$ )

Additional file 3: Table S3. Details of the $r b c L$ sequences that were curated from NCBI and BOLD system. (XLS $23 \mathrm{~kb}$ )

Additional file 4: Table S4. Details of the medicinal plant raw drugs collected and the outcome of authentication by DNA barcoding. (XLS $39 \mathrm{~kb}$ )

\section{Abbreviations}

API-RDBL, Ayurvedic Pharmacopoeia of India-reference DNA barcode library; BLAST, basic local alignment search tool; BOLD, Barcode of Life Database; $\mathrm{CBOL}$, Consortium for the Barcode of Life; CTAB, cetyl trimethyl ammonium bromide; DNA, deoxyribonucleic acid; EDTA, ethylene diamine tetraacetic acid; matK, maturase K; NCBI, National Center for Biotechnology Information; $P C R$, polymerase chain reaction; rbcL, ribulose-bisphosphate carboxylase

\section{Acknowledgements}

Financial support from The Central Council for Research in Ayurvedic Sciences (CCRAS), Government of India and SRM University is gratefully acknowledged.

\section{Authors' contributions}

PM and SLV conceived and designed the experiment. SLV, SN and BR performed the experiments. PM, SLV, SN and BR analyzed the data. PM and SLV wrote the manuscript. All authors read and approved the final manuscript.

\section{Competing interests}

The authors declare that they have no competing interests.

\section{Declarations}

The publication charges for this article were funded by the corresponding author's institution.

This article has been published as part of BMC Complementary and Alternative Medicine Volume 16 Supplement 1, 2016: Proceedings of the Indian Genetics Congress 2015: Complementary and Alternative Medicine. The full contents of the supplement are available online at http:// bmccomplementalternmed.biomedcentral.com/articles/supplements/ volume-16-supplement-1.

Published: 18 July 2016

\section{References}

1. Dasgupta S. A history of Indian philosophy. Delhi: Motilal Banarasidass; 1992

2. Mukherjee PK, Nema NK, Venkatesh P, Debnath PK. Changing scenario for promotion and development of Ayurveda-way forward. J Ethnopharmacol. 2012;143:424-34

3. Mukherjee PK, Wahile A. Integrated approaches towards drug development from Ayurveda and other Indian system of medicines. J Ethnopharmacol. 2006;103:25-35.

4. Bloomfield M. The Atharvaveda. Strassburg: Verla von Karl J Trobler; 1899

5. Sharma PV. Caraka Samhita (Text with English Translation). 9th ed. Varanasi: Chaukhambha Orientalia; 2005

6. Sharma RK, Dash. Caraka Samhita (Text in Sanskrit with English translation) Reprint ed. Vol 7: Oriental; 2006

7. Bhishagratna KKL. The Sushruta Samhita (An English Translation of the Sushruta Samhita Based on Original Sanskrit Text). Vol. 3: Kaviraj Kunja Lal Bhishagratna; 1916

8. Sharma PV Susruta Samhita. 3rd ed. Vol. 3. Chaukhambha Visvabharati: 2013.

9. WHO. Benchmark for training in Ayurveda. World Health Organization; 2010.

10. Central Drugs Standard Control Organization. The Drugs and Cosmetic Act; 1940.
11. Berra JL, Molho R. Ayurveda in Argentina and other Latin American countries. J Ayurveda Integr Med. 2010;1:225-30.

12. Samant SS, Dha U, Palni LMS. Himalayan Medicinal Plants: Potential and Prospects. Nainital: Gyanodaya Prakashan; 2002.

13. Ray P, Gupta HN. Charak Samhita (A Scientific Synopsis). Calcutta: Sree Saraswati; 1965.

14. Mukherjee PK. Quality Control of Herbal Drugs- An approach to evaluation of botanicals. 1st ed. India: Business Horizon; 2002.

15. Sharma S. Realms of Ayurveda. New Delhi: Arnold-Heinemann; 1979.

16. Department of AYUSH, Ministry of Health and Family Welfare, Government of India. The Ayurvedic Pharmacopoeia of India. 1st ed. Part 1: Vol. I: Department of AYUSH, Ministry of Health and Family Welfare, Government of India; 1990.

17. Department of AYUSH, Ministry of Health and Family Welfare, Government of India. The Ayurvedic Pharmacopoeia of India. 1st ed. Part 1: Vol. II, Department of AYUSH, Ministry of Health and Family Welfare, Government of India; 1999.

18. Department of AYUSH, Ministry of Health and Family Welfare, Government of India: The Ayurvedic Pharmacopoeia of India. 1st ed. Part 1: Vol. III, Department of AYUSH, Ministry of Health and Family Welfare, Government of India; 2001.

19. Department of AYUSH, Ministry of Health and Family Welfare, Government of India. The Ayurvedic Pharmacopoeia of India. 1st ed. Part 1: Vol. IV Department of AYUSH, Ministry of Health and Family Welfare, Government of India; 2004

20. Department of AYUSH, Ministry of Health and Family Welfare, Government of India. The Ayurvedic Pharmacopoeia of India. 1st ed. Part 1: Vol. V. Department of AYUSH, Ministry of Health and Family Welfare, Government of India; 2006.

21. Department of AYUSH, Ministry of Health and Family Welfare, Government of India. The Ayurvedic Pharmacopoeia of India. 1st ed. Part 1: Vol. VI, Department of AYUSH, Ministry of Health and Family Welfare, Government of India; 2008

22. Doyle JJ, Doyle JJ. A rapid DNA isolation procedure for small quantities of fresh leaf tissue. Phytochem Bull. 1987;9:11-5.

23. Vassou SL, Kusuma G, Parani M. DNA barcoding for species identification from dried and powdered plant parts: a case study with authentication of the raw drug market samples of Sida cordifolia. Gene. 2015:559:86-93.

24. Kress WJ, Wurdack KJ, Zimmer EA, Weigt LA, Janzen DH. Use of DNA barcodes to identify flowering plants. Proc Natl Acad Sci U S A. 2005;102: 8369-74.

25. Fazekas AJ, Burgess KS, Kesanakurti PR, Graham SW, Newmaster SG, Husband BC, et al. Multiple multi locus DNA barcode from the plastid genome discriminate plant species equally well. PLoS One. 2008:3:e2802.

26. Meier R, Shiyang K, Vaidya G, Ng PKL. DNA barcoding and taxonomy in Diptera: a tale of high intraspecific variability and low identification success. Syst Biol. 2006:55:715-28.

27. Tamura K, Peterson D, Peterson N, Stecher G, Nei M, Kumar S. MEGA5 molecular evolutionary genetics analysis using maximum likelihood, evolutionary distance, and maximum parsimony methods. Mol Biol Evol. 2011:28:2731-9.

28. Health Division Planning Commission Government of India. Report of steering committee on AYUSH for 12th five year plan. ST 2- AYUSH; 2012-17.

29. Hasebe M, Ito M, Kofuji R, Ueda K, Iwatsuki K. Phylogenetic relationships of ferns deduced from rbcL gene sequence. J Mol Evol. 1993:37:476-82.

30. Schaefer H, Hardy OJ, Silva L, Barraclough TG, Savolainen V. Testing Darwin's naturalization hypothesis in the Azores. Ecol Lett. 2011;14:389-96.

31. Cummings MP, Nugent JM, Olmstead RG, Palmer JD. Phylogenetic analysis reveals five independent transfers of the chloroplast gene $r b c L$ to the mitochondrial genome in angiosperms. Curr Genet. 2003;43(2): $131-8$.

32. Panero JL, Funk VA. The value of sampling anomalous taxa in phylogenetic studies: major clades of the Asteraceae revealed. Mol Phylogenet Evol. 2008 47(2):757-82.

33. Ndiribe C, Pellissier L, Antonelli S, Dubuis A, Pottier J, Vittoz P, et al. Phylogenetic plant community structure along elevation is lineage specific. Ecol Evol. 2013;3(15):4925-39.

34. China Plant BOL Group, Li DZ, Gao LM, Li HT, Wang H, Ge XJ, et al. Comparative analysis of a large dataset indicates that internal transcribed spacer (ITS) should be incorporated into the core barcode for seed plants. Proc Natl Acad Sci U S A. 2011;108(49):19641-6. 
35. Meizi L, Hui Y, Kun L, Pei M, Wenbin Z, Ping L. Authentication of Illicium verum using a DNA barcode psbA-trnH. J Med Plants Res. 2012;6(16):3156-61.

36. Chen S, Yao H, Han J, Liu C, Song J, Shi L, et al. Validation of the ITS2 region as a novel DNA barcode for identifying medicinal plant species. PLoS One. 2010;5(1):e8613.

37. Xi Z, Ruhfel BR, Schaefer H, Amorim AM, Sugumaran M, Wurdack KJ, et al. Phylogenomics and a posteriori data portioning resolve the Cretaceous angiosperm radiation Malpighiales. Proc Natl Acad Sci U S A. 2012;109(43): 17519-24.

38. Asmussen CB, Chase MW. Coding and noncoding plastid DNA in palm systematics. Am J Bot. 2001;88(6):1103-17.

39. Olmstead RG, Sweere JA. Combining data in phylogenetic systematics: An empirical approach using three molecular data sets in the Solanaceae. Syst Biol. 1994;43(4):467-81.

40. Gernandtad DS, Listonb A, Piñero D. Phylogentics of Pinus subsections Cembroides and Nelsoniae inferred from cpDNA sequences. Syst Biol. 2003; 28(4):657-73.

41. Olmstead RG, Reeves PA. Evidence for the polyphyly of the Scrophulariaceae based on chloroplast rbcL and ndhF sequences. Ann Missouri Bot Gard. 1995;82:176-93.

42. Bruni I, De Mattia F, Martellos S, Galimberti A, Savadori P, Casiraghi M, et al. DNA barcoding as an effective tool in improving a digital plant identification system: a case study for the area of Mt. Valerio, Trieste (NE Italy). PLoS One. 2012;7(9):e43256.

43. Kato H, Terauchi R, Utech FH, Kawano S. Molecular systematics of the Trilliaceae sensulato as inferred from $r b c L$ sequence data. Mol Phylogenet Evol. 1995;4(2):184-93.

44. Newmaster SG, Fazekas AJ, Ragupathy S. DNA barcoding in the land plants: evaluation of rbcL in a multigene tiered approach. Can J Bot. 2006;84:335-41.

45. Purushothaman N, Newmaster SG, Ragupathy S, Stalin N, Suresh D, Arunraj $\mathrm{DR}$, et al. A tiered barcode authentication tool to differentiate medicinal Cassia species in India. Genet Mol Res. 2014;13(2):2959-68.

46. Parvathy VA, Swetha VP, Sheeja TE, Sasikumar B. Detection of plant-based adulterants in turmeric powder using DNA barcoding. Pharm Biol. 2015;8:1-6.

47. Wallace LJ, Boilard SMAL, Eagle SHC, Spall JL, Shokralla S, Hajibabaei M. DNA barcodes for everyday life: Routine authentication of Natural Health Products. Food Res Int. 2012:49:446-52.

48. Kool A, Boer HJ, Kruge A, Rydberg A, Abbad A, Bjork L, et al. Molecular identification of commercialized medicinal plants in southern Morocco. PLoS One. 2012;7(6):e39459.

49. Newmaster SG, Grguric M, Shanmughanandhan D, Ramalingam S, Ragupathy S. DNA barcoding detects contamination and substitution in North American herbal products. BMC Med. 2013;11:222.

50. Stoeckle MY, Gamble CC, Kirpekar R, Young G, Ahmed S, Little DP. Commercial teas highlight plant DNA barcode identification successes and obstacles. Sci Rep. 2011;1:42.

\section{Submit your next manuscript to BioMed Central and we will help you at every step:}

- We accept pre-submission inquiries

- Our selector tool helps you to find the most relevant journal

- We provide round the clock customer support

- Convenient online submission

- Thorough peer review

- Inclusion in PubMed and all major indexing services

- Maximum visibility for your research

Submit your manuscript at www.biomedcentral.com/submit

C Biomed Central 